\section{US electronic highway needs consensus more than dollars}

\begin{abstract}
Washington. US vice president $\mathrm{Al}$ Gore has often likened his vision of a computer 'superhighway' to the interstate highway network built in the $1950 \mathrm{~s}$ and 1960 s for its potential to change the face of the country. But unlike that massive civil engineering project, Gore's plan to create a nationwide, high-capacity telecommunications network linking every home and office will require the federal government to first teach people how to drive and to set down the
\end{abstract} rules of the road.

The starting point for the administration's march towards an electronic super-highway is the high-speed networks now being tested at universities and government laboratories. One early is the transformation of NSFNET, supervised by the National Science Foundation, into a faster and more powerful research tool.

NSF plans to end its $\$ 10$-million support for the five-year-old, 45-megabit capacity NSFNET backbone and instead divert the money to its 20 regional networks

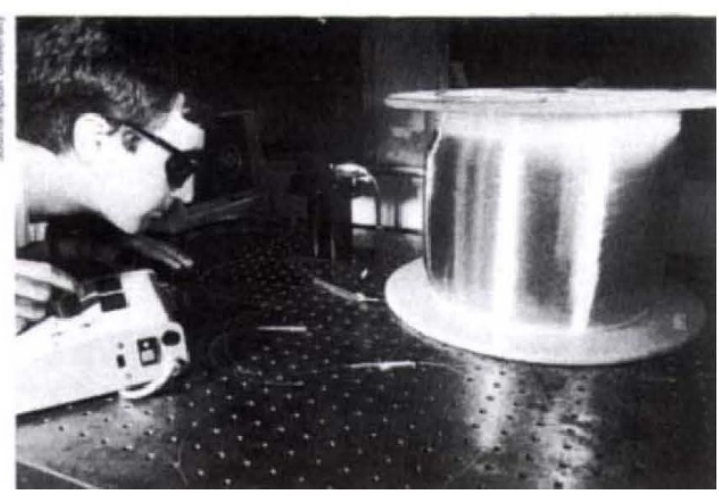

How far ahead is an optical fibre network? to link up via the commercial alternatives. At the same time, it will soon ask for bids for a more powerful link, of at least 155-megabit capacity, between five large supercomputing centres that need the extra capacity and speed, in the process laying a foundation for the next-generation national network. But these plans depend upon a \$7-million addition this year to the programme's \$30-million budget that is part of President Bill Clinton's \$16-billion economic stimulus package, an initiative held up by Republicans in the US Senate.

Regardless of the fate of that proposal, the outline of the generation that will succeed the 155-megabit network is already visible on the horizon: under the auspices of the National Research and Education Network (NREN), networks with capacities from 600 megabits to 2.5 gigabits are to be tested at five sites across the country. The government-wide NREN programme, which was created by the High Performance Computing and Communications Act of 1991 championed by Gore, expects to spend $\$ 400$ million in the next five years.

In the meantime, Stephen Wolff of NSF is keen to sce schools, libraries and other 'ordinary' users plug in to the existing 45megabit network. "The network needs to have a robust presence in each community, insulated from policy and funding fluctuations", he says.

A bill (S.4) introduced by Senator Ernest Hollings (Democrat, South Carolina) and supported by the Clinton administration would set up a national "information infrastructure programme" and would authorize several federal agencies to test high-speed network links to schools, libraries, hospitals and laboratories. An amendment would authorize extra money to pay schools and libraries to link up with NSFNET. Although some version of the Hollings bill - an overlapping and somewhat competing proposal (S.473) has been introduced by

\section{Senator Bennett Johnston (Democrat, Loui-} siana) - is likely to be passed, there are no plans to spend federal money on building any such network.

But the physical network is perhaps the easiest part of the jigsaw. "It is the software, applications, training, databases and getting people online that will be difficult", says Fiona Branton of the Computer Systems Policy Project, a computer industry lobby group.

The greatest impact of Clinton and Gore's strong political commitment to an electronic superhighway is likely to be on fixing the web of regulation that constrains private investment. The administration is in the process of appointing a task force on information infrastructure that would recommend a stable regulatory environment for highspeed telecommunications links. The computer industry strongly supports this proposal, believing that standard policies and protocols will give it a uniform home market for new products.

One important set of regulatory decisions will determine whether it makes commercial sense for US telecommunications companies to offer their customers services based on ISDN (Integrated Services Digital Network) in the near future. ISDN, which operates over copper wires, would serve as a stop-gap measure offering some digital communications. Its use may delay the immensely expensive construction of direct fibre-optic links to every home.

Colin Macilwain
NEWS IN BRIEF

New Delhi. Nine officials from the Indian subsidiary of the US Union Carbide Corporation will go on trial next month in connection with the release of methyl isocyanate gas from the company's Bhopal pesticides plant in December 1984 that killed more than 3,000 people and injured an estimated 200,000. Three others -- including the former chairman of Union Carbide, Warren Anderson - face a separate criminal case.

The charges, brought against senior company officials as well as technicians on site during the disaster, include culpable homicide and voluntarily causing grievous hurt. The company, Union Carbide India Ltd, has pleaded not guilty and plans to appeal against a recent ruling by a Bhopal court that company officials were guilty of criminal negligence. In February 1989 the Indian government accepted compensation of $\$ 470$ million in return for dropping further prosecution, but last year the Indian supreme court revoked that stipulation.

K.S.J.

London. The UK Medical Research Council is seeking bids for a small number of centres of excellence for research into gene therapy, with a guarantee of five years funding for applicants who can demonstrate an identified clinical goal, a coordinated approach spanning gene manipulation, gene delivery and cell biology, and clinical protocols that include detailed evaluation of the psychological and social aspects of gene therapy.

The new centres are expected to be built around the work of existing research groups, with funding used to recruit sufficient extra staff to provide what the council describes as a "critical and balanced mass of research". The centres will be financed with money recently awarded to the MRC by the government for promoting a genetic approach to human health.

D.D.

Tokyo. Japanese and European X-ray satellites have observed $X$-rays from a supernova detected on 28 March, continuing a lucky streak by Japanese space scientists. The observations are only the second from a supernova and the earliest ever, and both have occurred shortly after the launch of a Japanese X-ray satellite (see page 585).

In March 1987, Ginga was launched a few weeks before the discovery of SN1987A in the Large Magellanic Cloud; a few months later it recorded a burst of $X$-rays from the supernova. In February, Asuka was launched and last week detected very strong $X$-ray radiation from the new supernova. The $\mathrm{X}$-rays, in the range of $0.5-10 \mathrm{KeV}$, are believed to have appeared sooner this time because of the composition of the new supernova. It is thought to be a dense red super giant in contrast to the 1987 event, which resulted from the explosion of a less dense blue super giant.

D.S. 